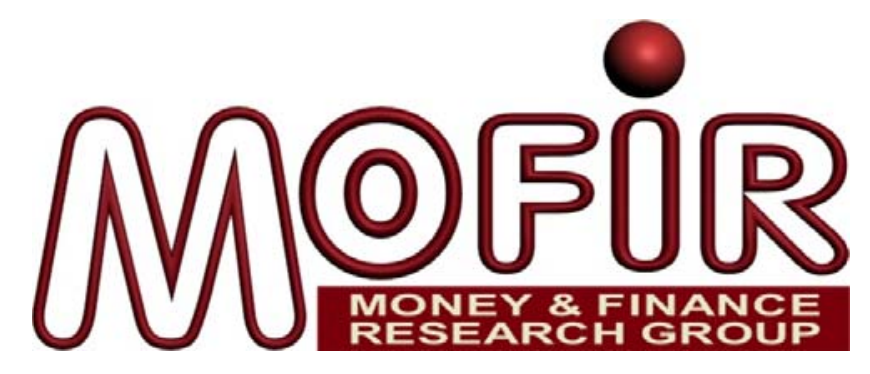

\title{
DO DOMESTIC AND CROSS-BORDER M\&AS DIFFER? CROSS-COUNTRY EVIDENCE FROM THE BANKING SECTOR
}

\author{
STEFANO CAIAZ7A \\ Università di Roma "Tor Vergata" \\ ALBERTO FRANCO POZZOLO \\ Università degli Studi del Molise \\ Centro Studi Luca d'Agliano \\ MoFiR \\ GIOVANNI TROVATO \\ Università di Roma "Tor Vergata"
}

MoFiR working paper $n^{\circ} 52$

J une 2011 


\title{
Do domestic and cross-border M\&As differ? Cross-country evidence from the banking sector
}

\author{
Stefano Caiazza \\ (Università di Roma "Tor Vergata") \\ Alberto Franco Pozzolo \\ (Università degli Studi del Molise, CASMEF, Centro d'Agliano and MoFiR) \\ Giovanni Trovato \\ (Università di Roma "Tor Vergata")
}

\begin{abstract}
$\underline{\text { Abstract }}$
Are the drivers of domestic and cross-border M\&As in the banking sector different? Despite the intense research on bank M\&As in the last decade, the attention paid to this issue is surprisingly limited. We fill this gap studying the ex-ante determinants of national and international acquisitions in the banking sector in an unbalanced panel of nearly 1,000 banks from 50 world countries, from 1992 to 2007. Our results show that size and profitability have a stronger impact on the probability that a bank is a bidder in a cross-border deal than in a domestic deal. Consistent with the findings of the literature on the determinants of the internationalization of manufacturing firms, international expansion in the banking sector is therefore easier for countries with a number of large "national champions", that are more capable to overcome the fixed costs of internationalization and have a stronger incentive to diversify the idiosyncratic risks of their domestic activities.
\end{abstract}

JEL classification: G15, G21, G34

Keywords: M\&As, bank, bank internationalization.

* Address for correspondence: Alberto Franco Pozzolo, Dipartimento di Scienze Economiche, Gestionali e Sociali, Università degli Studi del Molise, via de Sanctis, 86100, Campobasso, Italia. E-mails: caiazza@economia.uniroma2.it; pozzolo@unimol.it; giovanni.trovato@uniroma2.it. We would like to thank Michele Bagella, Iftekar Hasan and Giancarlo Spagnolo for comments and suggestions and seminar participants at the XV International "Tor Vergata" Conference on Banking and Finance, Rome, 5-7 December 2007. The standard disclaimers apply. We gratefully acknowledge financial support from the Italian Ministry for Education (Prin project no. 2006134152). 


\section{Introduction}

Since the early 1990s, deregulation and increased competition have determined a substantial increase in the number of mergers and acquisitions (M\&As) in the banking sector, from an average of 211 a year in the 1980s to 561 in the period from 1990 to 2006. While the scope of the consolidation process has been larger within domestic markets (Focarelli and Pozzolo, 2001), the number of cross-border operations has also increased considerably (Pozzolo, 2009), leading to radical changes in the shape of financial markets worldwide.

The intense activity in the takeover market for financial institutions has fostered the growth of an empirical literature analysing the determinants and consequences of these operations (see, e.g., the surveys by Amel et al., 2004, and DeYoung et al., 2010). The most typical operation has been found to be the acquisition of small and less efficient intermediaries by parts of relatively more profitable and efficient banks. While it is unclear whether or not this creates value for shareholders (as shown, e.g., by the influential but somewhat contrasting views in DeLong, 2001 and Houston et al., 2001), the evidence tends to point to the positive effects of takeovers in relation to indicators of corporate performance, such as profitability and efficiency (see, e.g., Focarelli et al., 2002; Focarelli and Panetta, 2003). But despite the progressive internationalization of the market for corporate control, the research attention paid to the differences between domestic and cross-border M\&As is surprisingly limited. The objective of this paper is to fill this gap by investigating whether the ex-ante determinants of crossborder M\&As in the banking sector differ from those related to domestic operations.

In broad terms, our work contributes to the understanding of the mechanisms driving contestability of corporate control. The competition of alternative teams in the takeover market for the right to manage corporate resources promotes better resource utilization (Jensen and Ruback, 1983; Andrade et al., 2001) and, in a world without friction, reallocation of control over companies would channel assets towards their best possible use (Rossi and Volpin, 2004). But in reality many frictions 
limit this process (Erel et al., 2009), possibly leading to inefficient equilibria. It is therefore important to understand what are the drivers of corporate operations, especially for financial companies, where the overwhelming presence of information asymmetries can severely limit contestability over corporate control.

More specifically, our research is linked to the literature studying the patterns and effects of domestics and cross-border bank expansion (Focarelli and Pozzolo, 2001 and 2008; Buch and DeLong, 2004; Berger et al., 2004; Gulamhussen et al., 2010). Indeed, although this literature has provided ample evidence that the domestic and cross-border M\&As are different - due, for example, to linguistic and cultural barriers, normative and institutional differences, less efficient information transmission, and higher fixed costs for the organization of transactions - to the best of our knowledge, a crosscountry investigation of these issues based on individual data is still lacking. ${ }^{1}$ We therefore build our analysis on an unbalanced panel of nearly 1,000 banks from 50 world countries, for the period from 1992 to 2007. Most important, we include in our sample both intermediaries that acquired participation in a domestic or foreign bank, as well as a control group of intermediaries that have not participated in bidding in a M\&A. Our rich data set has a two crucial characteristics that put us in a better position with respect to the previous analyses. First, with individual information on a large number of banks from many different developed and developing countries we can analyze the role of both bank specific characteristics such as size, profitability and specialization, and country specific characteristics, including institutional features. Second, the inclusion in the sample of a large number of banks that did not bid in an M\&A provides a control group that is a reliable benchmark with respect to which it is possible to compare the characteristics of the banks that are involved in corporate operations. ${ }^{2}$

\footnotetext{
${ }^{1}$ A recent exception is Correa (2009), who compares the characteristics of targets in domestic and cross-border deals.

${ }^{2}$ In theory, one might also be interested in studying simultaneously the characteristics of the targets of these M\&A operations, but this poses insurmountable problems of dimensionality. If we were to analyze the characteristics of each specific deal from the point of view of the bidders and of the targets, the correct control group would be the set of all possible M\&As, i.e., the product of all potential bidders with all potential targets. Clearly, the total set is far too wide and
} 
Our results confirm the previous evidence that banks more active in M\&As are larger and more profitable than their country peers. Moreover, they strengthen the previous indirect evidence on bank internationalization, showing that banks that bid cross-border are even larger than those that bid domestically, and they are relatively more liquid and better capitalized.

The rest of the paper is organized as follows. Section 2 briefly reviews the relevant empirical literature on bank M\&As and internationalization. Section 3 describes the data set; Sections 4 and 5 present the empirical model used for the estimations, and the results of the baseline specification and robustness checks. Section 6 concludes.

\section{Relevant literature}

In broad terms, the literature on bank M\&As can be classified into two groups that study, respectively, the ex-ante characteristics of bidders in M\&As and the ex-post effects. Further distinctions that are relevant for our analysis are between papers that focus on domestic and cross-border M\&As, and between analyses based on aggregate and on individual level data.

The literature on the determinants of bank M\&As, mostly based on bank specific information, is overwhelming. ${ }^{3}$ The generally agreed result is that the typical pattern is of larger and more efficient banks buying smaller and less efficient institutions. The reasons are straightforward: the acquirers, by sharing their superior management skills, create value by improving the profitability and efficiency of the acquired organization (Focarelli et al., 2002; Hannan and Pilloff, 2006). As for the ex-post effects, the evidence of improved bank efficiency is quite pervasive. Worthigton (2001), for example, shows that greater managerial ability, higher earnings, larger size, and the possibility of loan portfolio diversification are all features that increase the probability of a bank becoming a bidder in a M\&A operation. In the case of the results of mergers in the US, Kwan and Wilcox (2002) find evidence of

the incidence of M\&As far too small to allow sensible inference. Caiazza et al. (2010) analyze the characteristics of targets in a large sample of banks from over 100 countries, using as a control sample all potential targets.

${ }^{3}$ Recent surveys include Amel et al. (2004) and DeYoung et al. (2009). 
significant cost reductions, and Cornett et al. (2006) demonstrate increased revenue efficiency, especially in the case of operations that are activity and geographically focused. Huizinga et al. (2001) and Campa and Hernando (2006) provide evidence of cost efficiency improvements in the case of European mergers, and Altunbas and Marques-Ibáñez (2008) show that deals involving similar banks show better ex-post performance.

However, efficiency gains are not a guarantee that a bank merger will create value for shareholders, as shown by the results obtained for different countries, the specific characteristics of the merger (e.g., domestic versus cross-border or focusing versus diversifying), and the relative positions of the companies involved. Houston and Ryngaert (1994), for example, show that the stock market's response to large bank mergers is not value enhancing. ${ }^{4}$ De Long (2001) suggests that US geographic and activity focused mergers create value, while diversifying operations do not, a result that is also confirmed by Cornett et al. (2003). Goergen and Renneboog (2004) confirm these results showing that mergers are significantly value enhancing for targets, but much less so for bidders.

International M\&As are different from domestic operations. Research based on the aggregate number of cross-border operations between country pairs shows that banks are more likely to expand to countries with stronger economic, cultural, legal, and institutional linkages to their countries of origin, which are likely to reduce the impact of entry barriers (Buch and Delong, 2004; Berger et al., 2003 and 2004, Claessens and van Horen, 2007). Similar conclusions are drawn from analyses of bank crossborder reach based on individual level data (Focarelli and Pozzolo, 2005; Magri et al., 2005). Moreover, Focarelli and Pozzolo (2001) show that internationalization is less common in banking than in other sectors of economic activity, arguing that this is due to the more pervasive role of explicit and implicit barriers to foreign entry of credit institutions, than manufacturing firms (and even insurance companies; Focarelli and Pozzolo, 2008).

\footnotetext{
${ }^{4}$ The results of Campa and Hernando (2004) suggest that this is partly related to heavy regulation in the banking sector.
} 
As to the ex-post effects, consistent with the negative stock price reaction of geographically diversifying M\&As, Amihud et al. (2002) show that the bidders' returns on the announcement of a cross-border bank merger are negative. According to DeYoung et al. (2009), an explanation for these contrasting results might be that profit maximization is not the only motivation for a M\&A in the banking sector. As confirmed by many episodes in the recent financial crisis, motives such as power building by managers (Hughes et al,. 2003) and the research of a size that guarantees of being too-bigto-fail (Mishkin, 2006) may provide even more important incentives for bank M\&As than profit maximization.

Taken together, all these findings suggest that the implicit and explicit fixed costs for the acquirer will be much higher in the case of foreign expansions than for domestic deals. This would suggest that, along certain individual and country specific dimension, the characteristics of bidders in cross-border M\&As will be different from those of bidders in domestic operations. In what follows, we will examine this hypothesis in detail.

\section{Data and summary statistics}

To study the characteristics of bidders in domestic and cross-border M\&A deals, we need information on the banks involved in the mergers and data on the control group of institutions not involved in M\&A activity. Therefore, we consider initially an unbalanced panel of potential bidders from nearly 1,000 banks from 71 countries, whose total assets in 2006 were in excess of US\$25 billion, obtained from the Bankscope database provided by Bureau van Dijk. We concentrate on the larger banks in order that comparison between domestic and cross-border operations is not biased by the incidence of fixed costs, which will be disproportionately high for smaller banks involved in international deals.

Within this sample, we identify banks involved in M\&As using the information provided by Security Data Corporation (SDC) in their Platinum Worldwide Mergers and Acquisition Database, 
which includes the names, industry sectors, countries of residence, and several identification codes (e.g. ISIN and SEDOL) for the bidders and targets involved in M\&As, together with the announced and effective dates of these deals, and their status. We consider all bank M\&As effectively completed between 1988 and 2007. We define domestic M\&As as those where bidder and target bank nationalities are the same, and cross-border M\&As as those where nationalities differ. Our initial sample of M\&As includes nearly 12,000 deals. To merge the balance sheet and the M\&A datasets we use the SEDOL code, the identifier common to both databases, and then compare bank name and nationality text strings to cover the cases in which the SEDOL code is missing. We manually checked the string matches to remove improper attributions. Our final sample includes 7,434 observations for 923 banks from 50 countries between 1992 and 2007; 103 banks are involved in 456 domestic and 207 cross-border M\&As (clearly, many banks are involved in more than one operation).

Table 1 shows that our sample is biased towards the US. ${ }^{5}$ In fact, domestic mergers involving an American bank account for 79 per cent of total domestic deals; those involving a bank from a G10 country account for 91 per cent of all domestic deals. ${ }^{6}$ Germany is host country to the largest number of bidders in cross-border operations (21 per cent); the G10 countries host 55 per cent. Banks from Austria, Canada, France, Greece and Hungary are also very active in cross-border operations, while international deals with a US bank bidder are just 3 per cent of the total.

Figure 1 shows that domestic deals are evenly distributed across our sample period, with 56 per cent of the total number occurring before 2000. On the contrary, cross-border deals have been much less frequent before 2000 ( 21 per cent). This difference in the time distribution can be explained by two factors. First, at the start of the financial sector consolidation process that took place at the beginning of the 1990s, bidders probably watched for potential domestic targets, only later widening their focus to

\footnotetext{
${ }^{5}$ Additional analyses, available from the authors upon request, confirm that our results are broadly unchanged also excluding US banks.

${ }^{6}$ The official definition of G10 includes 11 countries: Belgium, Canada, France, Germany, Italy, Japan, the Netherlands, Sweden, Switzerland, UK and US. In our analysis, we exclude Sweden for reasons of data availability.
} 
foreign markets. Second, the regulatory and supervisory authorities may have become more favorable to the idea of foreign competitors (Carletti et al., 2006).

Tables 2 and 3 present some descriptive statistics for the data used in the empirical analysis. ${ }^{7}$ Data on GDP are from the International Monetary Fund's World Economic Outlook published in October 2009. Total GDP, expressed in PPP US\$ billions in 2000, ranges from 0.43 for Tonga to 9,545 billion for the US; on average it is 817.89 US\$ billions.

Stock market capitalization, private bank credit and total deposits are from the updated version of Beck et al. (2000), concentration is calculated from individual data. We consider three aggregate characteristics of the banking and financial markets. Concentration is measured as the ratio of the assets of a country's five largest banks to its total bank assets. The banking market is highly concentrated, with an average sample value of 91 per cent, although for many countries it is 100 per cent, implying that the top five banks represent entire coverage of the nation's banking system in our sample. Perhaps in part because of better market coverage, the US has the lowest concentration index (26 per cent), followed by Japan (49). Average concentration in the G10 countries is 75 per cent. Financial market specialization is measured as the ratio of stock market capitalization to private credit, and has an average value of 1.06. As it is customary in the literature, banking sector development is measured by the ratio of private credit to GDP; the average value is in this case is 0.79 , but it hides significant crosscountry differences. Stock markets are particularly large with respect to credit in South Africa (where the ratio is 2.87), Hong-Kong (2.68), US (2.44), and also the Russian Federation (2.19) and Turkey (1.71). Apart from Syria and Tonga, they are less developed in Austria (0.23), Cyprus (0.24), Portugal (0.31) and Germany (0.37), where bank intermediation is more important, as shown by the higher ratios

\footnotetext{
${ }^{7}$ We include in our descriptive statistics, as well as in our econometric analysis, also countries that had no domestic or cross-border M\&As during our sample period, as additional controls. Additional analyses available upon request confirm our results also excluding these countries.
} 
of private credit to GDP (ranging from 1.38 of Cyprus to 1.03 of Portugal, as opposed, for example, to 0.50 in the US).

Table 3 reports summary statistics for the individual bank indicators calculated for the sample of banks in each category in the year before the event occurred. For example, a domestic bidder in a domestic M\&A contributes its asset value in the year before a bid to the average value of the total assets of domestic bidders in domestic M\&As. Panel A reports the characteristics of the banking sector in each country, obtained aggregating our individual bank data from Bankscope. Average bank size, measured by total assets, is US\$112 billion. The largest banks are located in the Netherlands (US\$451bn), Switzerland (US\$311bn), France (US\$234bn) and Japan (US\$203bn). Cyprus and United Arab Emirates have the smallest banks. Bank returns on assets, a standard measure of profitability, is 0.76 per cent on average. The countries hosting the most profitable banks during our sample period are Hungary (2.46) and Iceland (2.25). French, German and UK banks have values below 0.5 per cent; similarly, the profitability of the G10 countries' banks is well below the sample average (0.52). The average share of other operative income to total income, often used as a proxy for the relative importance of traditional banking activities, is 0.51 , with a range of 0.05 in Israel to 1.02 in Australia ( 0.75 in the US); the average value for the G10 countries is 0.41 . The ratio of equity to total assets (the inverse of leverage), is 6.16 per cent on average, ranging from 12.99 in the Russian Federation to 1.29 in Syria (2.93 in Germany); in the G10s it is 4.81, lower than in the US (7.77). The ratio of liquid assets to deposits, a standard measure of the level of liquidity of the banking system is 19.92 per cent on average; in the G10 countries it is slightly lower (15.95); India and Turkey show the highest values (40.94 and 37.19, respectively), Saudi Arabia and Norway the lowest values (4.32 and 2.66). The cost to income ratio - a raw proxy for efficiency (Focarelli and Pozzolo, 2001; Vander Vennet, 2003) - is 
59.26 per cent on average, ranging from 75.64 in Iran to 16.64 in Syria. ${ }^{8}$ Among the G10 countries, the highest value is for Italy (67.93), the lowest for Germany (52.54).

Panel B, C and D of table 3 report statistics for individual bank indicators related, respectively, to non-bidders, domestic bidders and cross-border bidders. Consistent with the literature on banking internationalization, in our sample we find that the bidders in cross-border M\&As are the largest banks: the average bidder in a cross-border M\&A has a total assets value of US $\$ 427$ billions. The average bidder in a domestic M\&A has a significantly smaller value (US\$116bn), still larger than the value of non bidders (US\$102bn). Interestingly, bidders in domestic deals have on average higher returns on assets than bidders in cross-border operations (respectively, 1.21 and 0.84 per cent). The differences are even starker if we consider the medians. Cross-border bidders have a larger share of the revenues from traditional banking activities, with a share of other operative income to total income of only 30 per cent, as opposed to 39 per cent for domestic bidders. Non-bidder banks exhibit the largest ratio of income from non-traditional activity over total income (0.53). The average ratio of equity to total assets is lower for banks bidding in cross-border deals (i.e., these banks have higher leverage) than for those bidding in domestic deals (respectively, 5.15 and 7.86 per cent); the other banks are between these two values (6.08). The ratio of liquid assets to deposits is lower for banks involved domestic operations (9.92 per cent) compared to cross-border deals (11.08). The average value for other banks is 20.92 per cent. Finally, the cost to income ratio of bidding banks (61.64 and 60.44 for cross-border and domestic operations respectively) is higher than that of non-bidders (59.10).

Overall, these figures confirm most of the previous findings of the empirical literature on the determinants of M\&As, and support the indirect evidence on the characteristics of international banks, that are typically larger and more profitable than their peers. In the remaining of the paper, we will

\footnotetext{
${ }^{8}$ Costs are defined as the sum of net interests paid and operational costs; income is defined as total bank revenues.
} 
verify if the broad patterns emerging from these descriptive statistics are confirmed by a more rigorous econometric analysis.

\section{The empirical model}

To study the characteristics of bank M\&A bidders, we adopt a multinomial choice model in which we distinguish between non-bidders, bidders in domestic operations, and bidders in cross-border operations. In practice, we estimate the following specification: ${ }^{9}$

$$
\operatorname{Pr}\left(\mathrm{Y}_{i j t}=k\right)=\mathrm{F}\left(X_{i t-1}, B_{j t-1}, T D_{t}\right), \quad k=0,1,2
$$

where: $\mathrm{Y}_{i j t}=0$ if bank $i$ in country $j$ at time $t$ is not a bidder in any M\&A, $\mathrm{Y}_{i j t}=1$ if it is a bidder in a domestic M\&A, and $\mathrm{Y}_{i j t}=2$ if it is a bidder in a cross-border M\&A; $\mathrm{X}_{i t}$ are characteristics of bank $i$ at time $t ; \mathrm{B}_{j t}$ are characteristics of country $j$ at time $t$; and $T D_{t}$ are time dummies.

As bank specific characteristics we include the difference between the bank's individual value and the same variable's country and year average, therefore removing from the estimated coefficient of bank specific characteristics both time and country specific effects. In other words, the estimated coefficients measure the effect of the difference between a bank's characteristics and those of its average peer in the same country and in the same year. We choose this specification to disentangle the effects of cross-country and time heterogeneity, even in the absence of the country specific fixed effects. However, we verified that our results are qualitatively unchanged using a specification that includes country fixed effects. However, in some cases this led to the non-convergence of the maximization procedure for the likelihood function, and the comparison was therefore impossible.

\footnotetext{
${ }^{9}$ For the sake of comparison, we also estimate and present the results of a binomial choice model of the probability that a bank is an M\&A bidder, without distinguishing between domestic and cross-border operations.
} 
Since it is well known that multinomial choice models estimated using a logistic specification impose the hypothesis of independence of irrelevant alternatives, and we verified that the Hausman tests rejects this hypothesis in our sample, we use a multinomial probit specification. All standard errors are robust and clustered at country level.

\section{Empirical results}

\subsection{Baseline specification}

The choice of explanatory variables to include in our empirical model is mainly driven by the findings of the literature on bank M\&As, and include measures of size, profitability, specialization and efficiency.

We have argued above that there are many reasons why cross-border M\&As are more complex than domestic operations, and therefore it is very likely that the determinants of bank domestic and cross-border M\&As will differ, and that the average effects obtained from pooling both types of deals will hide some interesting additional economic content. Thus, in Table 4 we report the results from estimating the multinomial choice model of equation (1). For the sake of comparison, Panels 1 and 2 present the coefficients and the marginal effects of a binomial choice model of the probability that a bank is an M\&A bidder, respectively. Panels 3 to 6 present instead the results of the estimation of our baseline multinomial specification, distinguishing domestic and cross-border M\&As. Panels 3 and 4 report the coefficients and Panels 5 and 6 the marginal effects. Panel 7 shows the significance of the test for the differences between the parameters for the estimated probabilities of domestic and crossborder operations.

The results clearly confirm our main hypothesis that domestic and cross-border M\&As have partly different drivers. Panel 7 shows that in five cases the coefficient of the model for the probability that a bank is a bidder in a domestic M\&A is significantly different from that of the model for crossborder activity. 
Country characteristics. A first group of variables included in the analyses are country characteristics. Within this set, only economic development has a different effect on the probability that a bank bids in a domestic or in a cross-border deal. Higher GDP has a positive and significant effect on the probability that a bank is a bidder in a domestic deal, the same result as from the binomial model, but it has no effects on the probability that it bids internationally. The difference between the two coefficients is statistically significant at the $10 \%$ level. In other words, larger economies have more competitive takeover markets, but this does not impact on the ability of their national banks to merge with or acquire foreign financial intermediaries.

No other country characteristics have a significantly different effect on the probability that banks bid in domestic or cross-border merger deals. Consistent with the hypothesis that regulators hinder consolidation when it can negatively influence competition, banking sector concentration has a much stronger effect on the probability that a bank bids internationally, as confirmed by the larger marginal effect than in the case of domestic operations, but both coefficients are estimated with large standard errors and none of them is statistically significant. The coefficient of the country's financial market orientation is negative and statistically significant in both cases of domestic and cross-border M\&As, showing that the consolidation wave of the last decade was stronger in countries more orientated towards bank intermediation. In the case of cross-border deals, this result is also consistent with the findings of the literature on bank internationalization, showing that international bank are more likely to come from bank oriented countries (e.g., Focarelli and Pozzolo, 2001 and 2005). Finally, the sheer size of the banking market relative to total GDP has no significant effects on the probability that banks will be M\&A bidders, in both the binomial and the multinomial specifications.

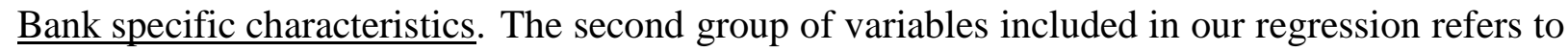
bank specific characteristics, expressed as differences with respect to country and year averages. Consistent with our expectations, the results show that banks are more likely to bid in an M\&A if they 
are: a) larger; b) more profitable; c) less liquid; d) more oriented towards traditional banking activities; and e) have a higher cost to income ratio. Although the signs of these effects is the same on the probability of domestic and cross-border deals, the magnitudes are significantly different in three out of six cases.

As we argued above, it is a standard finding in the empirical literature that larger and more profitable banks are more likely to acquire or merge with other institutions (Focarelli et al., 2002). However, the effect of size is significantly stronger in the case of cross-border operations, confirming also for the banking industry the general result that only large corporations have the incentives and the means to overcome the high fixed costs that are necessary to expand internationally (Helpman et al., 2004). On the contrary, profitability seems to be more relevant in the case of domestic deals, as shown by the larger marginal effect, although the difference with respect to the likelihood of bidding in crossborder operations is small and statistically insignificant. Liquidity has a negative impact in the case of both domestic and international deals, but only in the first case the coefficient is statistically significant. The results are consistent with the hypothesis that banks try to reduce the risk of liquidity shocks through mergers (Focarelli et al., 2002), but it suggests that this strategy is not a major driver in the case of cross-border participations, most likely because the limitations to the international transfer of liquidity that are imposed by regulators also within subsidiaries of the same banking group limit its viability.

The negative and significant effect of the incidence of non traditional banking activities is partly in contrast with the finding that innovative banks are typically more active in the Italian takeover market (Focarelli et al., 2002). On the contrary, it shows that large and profitable banks specialized in traditional activities enter more innovative markets precisely through the acquisition of more specialized intermediaries, an interpretation that is indeed consistent with the findings of Caiazza et al. (2010), who show that domestic M\&A targets have a larger share of the revenues from non-traditional 
banking activities. Our results also show that this effect is smaller in the case of cross-border deals. Interestingly, banks with a higher cost to income ratio are more likely to bid in both domestic and cross-border M\&As. While the marginal effect is much smaller than for the other bank specific characteristics, this result suggests that our rough measure of cost efficiency is not a relevant characteristic in the domestic and international markets for corporate control, and it may indeed capture instead higher average labor costs, that are typically associated with a more specialized labor force. ${ }^{10}$ Finally, a lower level of equity of total assets (a higher leverage) has a negative effect on the probability that a bank bids domestically and a positive effect that it bids internationally. However, although the two coefficients are significantly different from each other at the 5 per cent level, none of them turns out being significantly different from zero.

Average bank characteristics. Finally, a third set of variables included in the regression refers to the year and country averages of bank specific characteristics that were subtracted from individual bank data to obtain our previous set of regressors. Interestingly, the effects of year and country averages go in the same direction as those of bank specific characteristics, with the only important exception of that of average size. ${ }^{11}$

Banks are more likely to bid in an M\&A when they operate in countries where average liquidity is lower - confirming that liquidity search is a relevant motivation for bank mergers - and where average profitability is higher. However, the effects are not significantly different on the probability that of domestic and cross-border bids. More surprisingly, average bank size has a negative and statistically significant effect on the probability that banks take an active part in an M\&A operation, both domestically and internationally. In the case of domestic deals, this results may be explained by the fact that it is easier for banks to bid in an M\&A in countries where banks are on average smaller,

\footnotetext{
${ }^{10}$ Indeed, in a companion paper (Caiazza et al., 2009) in which we model technical efficiency more rigorously, using parametric and semi-parametric techniques, we find that more efficient banks are more likely to bid in cross-border operations.

${ }^{11}$ We checked that this results is not driven by the number of bank operating in each country.
} 
since there is a larger number of potentially affordable targets. In the case of cross-border deals, the negative effect is less sizeable, as confirmed by the smaller marginal effect, but its explanation seems more puzzling.

We find no statistically significant evidence that average specialization, measured by the ratio of other operative income over total income, and average cost to income, our raw proxy for efficiency, affect the probability that a bank is active in an M\&A deal. Finally, the average ratio of equity to total assets (the inverse of leverage) has no statistically significant effect on the probability that a bank is an M\&A bidder in a domestic operation, but it has a significant negative effect on the probability that it bids internationally, and the difference between the two coefficients is statistically significant at the 10 per cent level.

The comparison of the average marginal effects over the estimation sample provide additional information about the relevance of the explanatory variables included in the regression. The variables with a stronger statistically significant effect on the probability that a bank is a bidder in a domestic M\&A are the country's financial specialization, its total GDP and its average bank profitability. Among individual bank characteristics, the strongest impact are those of the incidence of traditional banking activities and of profitability. In the case of cross-border M\&As, the strongest impact comes from the country's financial specialization and from average bank profitability and, at the individual bank level, from size.

\subsection{G10 countries}

Since the determinants of M\&As might be different in richer countries, that have more developed financial markets and better institutional environments, than in poorer countries, in Table 5 we present the results obtained estimating the model of equation (1) on the sub-sample of banks based in G10 countries. Although they broadly confirm the findings obtained from the full sample, they still show

some interesting differences. The structure of Table 5 replicates that of Table 4 . As in the previous 
case, Panel 7 clearly confirms the existence of significant differences between the determinants of domestic and cross-border M\&As: in six cases the coefficient of the model for the probability that a bank is a bidder in a domestic M\&A is significantly different from that of the model for cross-border activity. However, only in three cases the differences are between those same coefficients that differed in the estimates from the entire sample.

The estimates of the effects of country characteristics obtained from the smaller sample of the countries of the G10 group are obviously much less reliable than those from the entire sample, but they nonetheless broadly confirm the previous. Economic development has a positive and significant effect on the probability that a bank is a bidder in a domestic deal and an insignificant effect in the case of cross-border operations, as in the case of the estimates on the entire sample. However, due to the smaller number of countries, the difference between the two coefficients is not statistically significant. Banking sector concentration has no statistically significant effect on the probability that a bank bids in an M\&A, although the coefficient is surprisingly positive in the case of domestic deals and negative in that of cross-border operations, and the difference between the two is statistically significant at the 10 per cent level. The effect of the country's financial market orientation is negative and statistically significant in both cases of domestic and cross-border M\&As, but in the case of domestic deals the effect is much stronger, and the difference between the two coefficients is also statistically significant, at the 5 per cent level.

The results on the effects of bank specific characteristics are statistically more reliable, since also in the case of the smaller sample of G10 countries are based on a set of over 4,000 observations. Overall, they confirm the findings of the estimates from the entire sample. Banks that are larger, more profitable, less liquid, more oriented towards traditional banking activities and have a higher cost to income ratio are indeed more likely to bid in an M\&A. As expected, also in the estimates within the G10s the coefficient of size is significantly larger in the case of cross-border deals, although the 
marginal effects are in this case comparable. Interestingly, the results of the opposite effects of leverage for domestic and cross-border deals is also confirmed but, as in the case of the estimates on the entire sample, none of the two individual coefficients is statistically significant.

Finally, also the results for year and country averages of bank specific characteristics are similar to those from the baseline specification. However, within the G10s, in addition to the ratio of equity to total assets (the inverse of leverage), also the liquidity ratio has a significantly different effect on the probability that a bank bids domestically or internationally.

Interestingly, the size of the marginal effects and their internal ranking are also quite different from those obtained from the entire sample. In particular, within the G10s, by far the strongest impact on the probability that a bank bids in an M\&A deal comes from average liquidity.

\section{Conclusions}

The economic literature provides extensive analyses of why banks bid in an M\&A. However, the differences between domestic and cross-border deals have not been studied in depth so far. This paper analyzes the characteristics of banks (and the countries in which they operate) that make it more likely that they will be bidders in domestic or in cross-border M\&As.

The results of our econometric analysis show that banks more active in M\&As are larger, more profitable, more oriented towards traditional banking activities, less liquid, and are located in countries with higher GDP and with financial markets more oriented to banking intermediation than stock market transactions. Further, when we distinguish between domestic and cross-border operations, we obtain additional interesting information, showing that individual bank size is significantly more important for cross-border deals than for domestic M\&As. This confirms that size is essential for cross-border expansion, consistent with the findings of the literature on the determinants of the internationalization of manufacturing firms. From a policy perspective, bank internationalization has been and will be easier for countries with a presence of a number of large "national champions". 


\section{References}

Altunbas, Y., Marques-Ibáñez, D., 2008. Mergers and acquisitions and bank performance in Europe: The role of strategic similarities. Journal of Economics and Business 60, 204-222.

Amel, D., Banes, C., Panetta, F., Salleo, C., 2004. Consolidation and efficiency in the financial sector: A review of the international evidence. Journal of Banking and Finance 28, 2493-2519.

Amihud, Y., Delong, G.L., Saunders, A., 2002. The Effects of Cross-Border Bank Mergers on Bank Risk and Value. Journal of International Money and Finance 21, 857-877.

Andrade, G., Mitchel,1 M., Stafford, E., 2001. New evidence and perspectives in mergers. Journal of Economic Perspectives 15, 103-120.

Beck, T., Demirgüç-Kunt, A., Levine, R., 2000. A new database on financial development and structure. World Bank Economic Review 14, 597-605, revised in 2006.

Berger, A.N., Hunter, W.C., Timme, S.G., 2003. The efficiency of financial institutions: a review and preview of research past, present, and future. Journal of Banking and Finance 17, 221-49.

Berger, A.N., Buch, C.M., DeLong, G.L., DeYoung R., 2004. Exporting financial institutions management via foreign direct investment mergers and acquisitions. Journal of International Money and Finance 22, 333-366.

Buch, C.M., DeLong, G.L., 2004. Cross-border bank mergers: what lures the rare animal?. Journal of Banking and Finance 28, 2077-2102.

Caiazza, S., Pozzolo, A.F., Trovato, G., 2009. Bank efficiency measure, M\&A decision and heterogeneity: a semi-parametric application. mimeo.

Caiazza, S., Clare, A.D., Pozzolo, A.F., 2010. What Do Foreigners Want? Evidence from Targets in Bank Cross-Border M\&As. Available at SSRN: http://ssrn.com/abstract=1703524.

Campa, J.M., Hernando, I., 2004, Shareholder Value Creation in European M\&As. European Financial Management 10, 47-81.

Campa, J.M., Hernando, I., 2006. M\&As performance in the European financial industry. Journal of Banking and Finance 30, 3367-3392.

Carletti, E., P. Hartmann and S. Ongena (2006), "Cross-border banking and competition policy, European Central Bank Research Bulletin, 4, 7-10.

Claessens, S., van Horen, N., 2007. Location decisions of foreign banks and competitive advantage. Available at SSRN: http://ssrn.com/abstract=904332.

Cornett, M.M., Hovakimian, G., Palia, D., Tehranian, H., 2003. The impact of the managershareholder conflict on acquiring bank returns. Journal of Banking and Finance 27, 103-131.

Cornett, M.M., McNutt, J.J., Tehranian, H., 2006. Performance changes around bank mergers: Revenue enhancements versus cost reductions. Journal of Money, Credit, and Banking 38, 1013-1050. 
Correa, R., 2009. Cross-border Bank Acquisitions: Is there a Performance Effect?. Journal of Financial Services Research 36, 169-197.

DeLong G.L., 2001, Stockholder gains from focusing versus diversifying bank mergers, Journal of Financial Economics 59, 221-252.

DeYoung, R., Douglas, E., Molyneux, P., 2009. Mergers and Acquisitions of Financial Institutions: A Review of the Literature. Journal of Financial Services Research 36, 87-110.

DeYoung, R., Hunter, W.C., Udell, G.F., 2004. The past, present, and probable future for community banks. Journal of Financial Services Research 25, 85- 133.

Erel, I., Liao, R.C., Weisbach, M.S., 2009. World markets for mergers and acquisitions. NBER WP no. 15132 .

Focarelli, D., Panetta, F., Carmelo, S., 2002. Why do banks merge?. Journal of Money Credit and Banking 34, 1047-66.

Focarelli, D., Panetta, F., 2003. Are mergers beneficial to consumers? Evidence from the market for bank deposits. American Economic Review 93, 1152-1172.

Focarelli, D., Pozzolo, A.F., 2001. The patterns of cross-border bank mergers and shareholdings in OECD countries. Journal of Banking and Finance 25, 2305- 2337.

Focarelli, D., Pozzolo, A.F., 2005. Where do banks expand abroad? An empirical analysis. Journal of Business 78, 2035-2065.

Focarelli, D., Pozzolo, A.F., 2008. Cross-border M\&As in the financial sector: Is banking different from Insurance?. Journal of Banking and Finance 32, 15-29.

Goergen, M., Renneboog, L., 2004. Shareholder Wealth Effects of European Domestic and Crossborder Takeover Bids. European Financial Management 10, 9-45

Gulamhussen, M.A, Pinheiro, Pozzolo, A.F., 2010, Do multinational banks create or destroy economic value?. Mo.Fi.R. Working Papers 36, 2010.

Hannan, T.H., Pilloff, S.J., 2006. Acquisition targets and motives in the banking industry. Federal Reserve Board Finance and Economics Discussion Series 2006-40.

Helpman, E., M.J. Melitz, S.R. Yeaple. (2004). Export versus FDI with heterogeneous firms. American Economic Review 94, 300-16.

Houston, J., James, C.M., Ryngaert, M., 2001. Where do merger gains come from? Bank mergers from the perspective of insiders and outsiders. Journal of Financial Economics 60, 285-331.

Houston, J., Ryngaert, M., 1994. The overall gains from large bank mergers. Journal of Banking and Finance 18, 1155-1176.

Hughes, J., Lang ,W., Mester, L., Moon, C.G., Pagano, M., 2003. Do bankers sacrifice value to build empires? Managerial incentives, industry consolidation, and financial performance. Journal of Banking and Finance 27, 417-447. 
Huizinga, H.P., Nelissen, J.H.M., Vander Vennet, R., 2001. Efficiency effects of bank mergers and acquisitions in Europe. Ghent University Working Paper No 106.

Jensen, M.C., Ruback, L.S., 1983. The Market For Corporate Control: The Scientific Evidence. Journal of Financial Economics 11, 5-50.

Kwan, S., Wilcox, J., 2002. Hidden cost reduction in bank mergers: Accounting for more productive banks. Research in Finance 19, 109-124.

Magri, S., Mori, A., Rossi, P., 2005. The entry and the activity level of foreign banks in Italy: An analysis the determinants. Journal of Banking and Finance 29,1295-1310.

Mishkin, F.S. , 2006. How big a problem is too big to fail?. Journal of Economic Literature 44, 9881004.

Pozzolo, A.F., 2009, Bank cross-border mergers and acquisitions (causes, consequences and recent trends), in: Alessandrini, P., Fratianni, M., Zazzaro, A., (Eds.), The Changing Geography of Banking and Finance, Norwell, Springer.

Rhoades ,S. A., 1994. A Summary of Merger Performance Studies in Banking, 1980-93, and an Assessment of the 'Operating Performance' and 'Event Study' Methodologies. Federal Reserve Board, Staff Study 167.

Rossi, F., Volpin, P.F., 2004. Cross-country determinants of mergers and acquisitions. Journal of Financial Economics 74, 277-304.

Vander Vennet, R., 2003. Cross-border mergers in european banking and bank efficiency, in: Herrmann, H., Lipsey, R. (Eds.), Foreign Direct Investment in the Real and Financial Sector of Industrial Countries. Springer, Heidelberg and New York.

Worthington, A.C., 2001. Efficiency in pre-merger and post-merger non-bank financial institutions. Managerial and Decision Economics 22, 439-452. 


\section{Number of domestic and cross-border M\&As by country}

Number of domestic and cross-border mergers and acquisitions that took place between 1992 and 2007 as registered in the Platinum Worldwide Mergers and Acquisition Database produced by Security Data Corporation (SDC).

Domestic

\begin{tabular}{|c|c|c|c|}
\hline Australia & 0 & 6 & 6 \\
\hline Austria & 6 & 27 & 33 \\
\hline Belgium & 1 & 0 & 1 \\
\hline Brazil & 10 & 1 & 11 \\
\hline Canada & 11 & 31 & 42 \\
\hline China & 0 & 1 & 1 \\
\hline Czech Republic & 1 & 0 & 1 \\
\hline Denmark & 0 & 3 & 3 \\
\hline Finland & 0 & 2 & 2 \\
\hline France & 1 & 21 & 22 \\
\hline Germany & 17 & 44 & 61 \\
\hline Greece & 0 & 17 & 17 \\
\hline Hungary & 1 & 10 & 11 \\
\hline Iceland & 0 & 3 & 3 \\
\hline India & 3 & 3 & 6 \\
\hline Israel & 4 & 1 & 5 \\
\hline Italy & 9 & 5 & 14 \\
\hline Japan & 16 & 1 & 17 \\
\hline Korea, Rep. & 1 & 2 & 3 \\
\hline Malaysia & 2 & 2 & 4 \\
\hline Netherlands & 1 & 6 & 7 \\
\hline Norway & 0 & 1 & 1 \\
\hline Poland & 0 & 1 & 1 \\
\hline Portugal & 1 & 1 & 2 \\
\hline Russian Fed & 1 & 2 & 3 \\
\hline Singapore & 0 & 2 & 2 \\
\hline South Africa & 1 & 0 & 1 \\
\hline Spain & 1 & 4 & 5 \\
\hline Taiwan & 8 & 0 & 8 \\
\hline Thailand & 1 & 0 & 1 \\
\hline United Kingdom & 1 & 4 & 5 \\
\hline United States & 358 & 6 & 364 \\
\hline Total & 456 & 207 & 663 \\
\hline
\end{tabular}


Number of domestic and cross-border M\&As by year

Figure 1

Number of domestic and cross-border mergers and acquisitions between 1992 and 2007, filed in the Platinum Worldwide Mergers and Acquisition Database produced by Security Data Corporation (SDC).

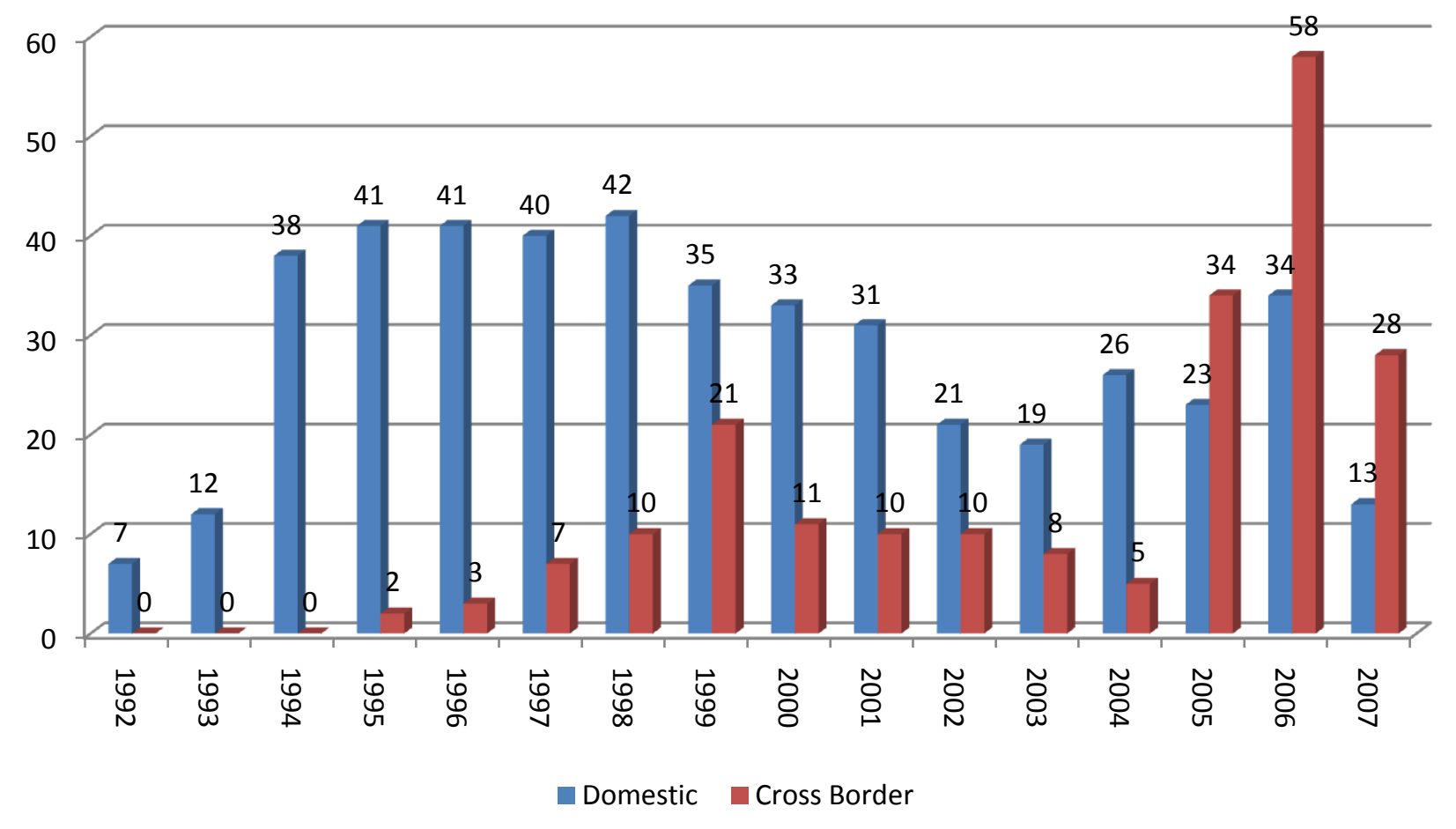




\section{Summary statistics for country-specific variables}

$G D P$ is the gross domestic product based on purchasing-power parity (PPP) in 2000, expressed in billions of US dollars. Concentration is the market share of the five largest banks measured by total assets. Stock market capitalization / total credit is the ratio between the stock market capitalization and total credit to the private sector. Private credit / GDP is the ratio between total credit to the private sector and GDP. Data on GDP is from the IMF; stock market capitalization and private credit are from Beck et al.(2000), revised in 2006. Concentration is obtained as country average of bank individual data from Bankscope. Statistics are obtained trimming the first and last percentiles of the sample distribution of each variable.

\begin{tabular}{|c|c|c|c|c|}
\hline Country & GDP & Concentration & $\begin{array}{c}\text { Stock market capitalization / } \\
\text { Private credit }\end{array}$ & $\begin{array}{l}\text { Private credit / } \\
\text { GDP }\end{array}$ \\
\hline Australia & 652.22 & 0.94 & 1.18 & 0.99 \\
\hline Austria & 244.54 & 0.84 & 0.23 & 1.03 \\
\hline Belgium & 259.92 & 0.94 & 0.73 & 0.71 \\
\hline Brazil & $1,305.89$ & 0.80 & 1.18 & 0.31 \\
\hline Canada & 887.58 & 0.89 & 0.97 & 0.97 \\
\hline Cayman Islands & & & . & . \\
\hline China & $3,505.68$ & 0.90 & . & . \\
\hline Cyprus & 13.38 & 1.00 & 0.24 & 1.38 \\
\hline Czech Republic & 155.40 & 1.00 & 0.51 & 0.49 \\
\hline Denmark & 149.25 & 1.00 & 0.89 & 0.88 \\
\hline Egypt & 229.30 & 1.00 & 0.64 & 0.39 \\
\hline Finland & 128.00 & 1.00 & 1.21 & 0.65 \\
\hline France & $1,570.76$ & 0.74 & 0.74 & 0.88 \\
\hline Germany & $2,095.93$ & 0.80 & 0.37 & 1.08 \\
\hline Greece & 283.07 & 0.91 & 0.70 & 0.71 \\
\hline Hong Kong & 234.50 & 0.91 & 2.68 & 1.43 \\
\hline Hungary & 141.06 & 1.00 & 0.70 & 0.36 \\
\hline Iceland & 10.34 & 1.00 & 0.73 & 1.91 \\
\hline India & $2,039.09$ & 0.94 & 1.29 & 0.33 \\
\hline Indonesia & 598.38 & 1.00 & 1.10 & 0.22 \\
\hline Iran & 519.18 & 1.00 & 0.77 & 0.22 \\
\hline Ireland-Rep & 128.30 & 0.91 & 0.53 & 1.14 \\
\hline Israel & 115.42 & 1.00 & 0.71 & 0.71 \\
\hline Italy & $1,379.24$ & 0.70 & 0.48 & 0.70 \\
\hline Japan & $3,280.67$ & 0.49 & 0.56 & 1.48 \\
\hline Jordan & 15.55 & 1.00 & 1.34 & 0.67 \\
\hline Korea, Rep. & 767.85 & 0.64 & 0.65 & 0.69 \\
\hline Kuwait & 70.28 & 1.00 & 1.81 & 0.40 \\
\hline Luxembourg & 24.15 & 0.84 & 1.33 & 1.07 \\
\hline Malaysia & 221.45 & 1.00 & 1.48 & 1.20 \\
\hline Mexico & $1,109.72$ & 1.00 & 1.56 & 0.16 \\
\hline Netherlands & 571.49 & 0.92 & 0.60 & 1.59 \\
\hline New Zealand & 75.63 & 1.00 & 0.42 & 1.05 \\
\hline Norway & 181.14 & 1.00 & 0.59 & 0.68 \\
\hline Poland & 523.67 & 1.00 & 0.99 & 0.28 \\
\hline Portugal & 171.35 & 1.00 & 0.31 & 1.03 \\
\hline Russian Fed & $1,363.36$ & 1.00 & 2.19 & 0.17 \\
\hline Saudi Arabia & 361.25 & 1.00 & 1.74 & 0.25 \\
\hline Singapore & 145.19 & 1.00 & 2.10 & 0.93 \\
\hline South Africa & 358.93 & 0.79 & 2.87 & 0.65 \\
\hline Spain & $1,003.33$ & 0.83 & 0.58 & 1.12 \\
\hline Switzerland & 226.77 & 1.00 & 1.27 & 1.59 \\
\hline Syria & 52.91 & 1.00 & . & 0.09 \\
\hline Taiwan & & . & . & \\
\hline Thailand & 289.35 & & 0.27 & 1.43 \\
\hline Tonga & 0.43 & 1.00 & . & 0.50 \\
\hline Turkey & 597.74 & 0.89 & 1.71 & 0.15 \\
\hline United Kingdom & $1,572.82$ & 0.76 & 1.05 & 1.30 \\
\hline United States & $9,544.78$ & 0.26 & 2.44 & 0.50 \\
\hline Utd Arab Em & 82.54 & 1.00 & & \\
\hline
\end{tabular}




\section{Summary statistics for bank-specific variables}

Panel A reports the statistics for the entire sample, trimming the first and last percentiles of the sample distribution of each variable. Panel B reports the statistics for banks not involved in any deal. Panels C and D report the statistics for banks involved in domestic deals and cross-border deals, respectively. Summary statistics are calculated for the sample of banks in each category in the year before the event has taken place. Total assets is the total amount of bank's asset expressed in billions of US dollars. Return on (average) asset is the ratio between bank returns and total asset, expressed in percentage. Other income over total income is the ratio between the sum of income from non-traditional activities (eg net fees and commission and net trading income) and total income. Equity / assets, the inverse of leverage, is the percentage ratio between equity and total asset. Liquid assets to deposits is the ratio between liquid assets and total deposits, expressed in percentage. Cost / income is the percentage ratio between total costs and total income. Data are from Bankscope.

\begin{tabular}{|c|c|c|c|c|c|c|}
\hline Variable & Obs. & Mean & Median & St. dev. & Minimum & Maximum \\
\hline \multicolumn{7}{|c|}{ A. Banks with total assets of more than \$25 Billion } \\
\hline Total Assets & 7,434 & 112.00 & 39.10 & 216.00 & 0.00 & $1,960.00$ \\
\hline Return on Asset & 7,033 & 0.76 & 0.67 & 0.72 & -1.95 & 3.82 \\
\hline Other Inc. / Total Income & 6,420 & 0.51 & 0.23 & 0.92 & -0.77 & 8.57 \\
\hline Equity / Assets & 7,281 & 6.16 & 5.70 & 3.50 & 0.34 & 25.73 \\
\hline Liquid Assets / Deposits & 6,863 & 19.92 & 12.03 & 22.19 & 0.05 & 112.47 \\
\hline Cost / Income & 7,078 & 59.26 & 59.31 & 23.32 & 0.00 & 729.15 \\
\hline \multicolumn{7}{|c|}{ B. Banks not involved in M\&As } \\
\hline Total Assets & 6,771 & 102.00 & 38.00 & 198.00 & 0.00 & $1,960.00$ \\
\hline Return on Asset & 6,376 & 0.72 & 0.62 & 0.73 & -1.95 & 3.82 \\
\hline Other Inc. / Total Income & 5,776 & 0.53 & 0.22 & 0.96 & -0.77 & 8.57 \\
\hline Equity / Assets & 6,618 & 6.08 & 5.53 & 3.57 & 0.34 & 25.73 \\
\hline Liquid Assets / Deposits & 6,217 & 20.92 & 12.84 & 22.88 & 0.05 & 112.47 \\
\hline Cost / Income & 6,419 & 59.10 & 59.94 & 24.30 & 0.00 & 729.15 \\
\hline \multicolumn{7}{|c|}{ C. Banks involved in domestic M\&As } \\
\hline Total Assets & 456 & 116.00 & 39.10 & 228.00 & 1.16 & 1730.00 \\
\hline Return on Asset & 453 & 1.21 & 1.25 & 0.51 & -0.49 & 3.68 \\
\hline Other Inc. / Total Income & 446 & 0.39 & 0.27 & 0.50 & -0.26 & 5.27 \\
\hline Equity / Assets & 456 & 7.86 & 7.93 & 2.21 & 2.35 & 18.53 \\
\hline Liquid Assets / Deposits & 442 & 9.92 & 7.37 & 9.20 & 0.56 & 79.16 \\
\hline Cost / Income & 455 & 60.44 & 60.57 & 8.86 & 22.40 & 93.90 \\
\hline \multicolumn{7}{|c|}{ D. Banks involved in cross-border M\&As } \\
\hline Total Assets & 207 & 427.00 & 251.00 & 430.00 & 8.21 & $1,660.00$ \\
\hline Return on Asset & 204 & 0.84 & 0.68 & 0.69 & -0.49 & 3.45 \\
\hline Other Inc. / Total Income & 198 & 0.30 & 0.22 & 0.31 & -0.46 & 1.82 \\
\hline Equity / Assets & 207 & 5.15 & 4.73 & 2.18 & 2.62 & 11.86 \\
\hline Liquid Assets / Deposits & 204 & 11.08 & 10.27 & 10.01 & 0.08 & 71.90 \\
\hline Cost / Income & 204 & 61.64 & 61.59 & 10.65 & 30.44 & 90.74 \\
\hline
\end{tabular}




\section{Characteristics of bank M\&A bidders}

In the binomial specification, the dependent variable takes the value of one if the bank is a bidder in any M\&A and zero otherwise. In the multinomial specification, the dependent variable takes the value of two if the bank is a bidder in a crossborder M\&A, one if it is a bidder in a domestic M\&A and zero otherwise. Both models are estimated using a (binomial or multinomial) probit specification. All independent variables are lagged one period. For variable definitions see the notes to Tables 1-3. Robust standard errors adjusted for clustering at the country level are reported in parenthesis. Panel 7 reports the significance of the test of the difference between the coefficients of domestic deals (Panel 3) and of cross-border deals (Panel 4). The symbol *** indicates a significance level of 1 per cent or less; ** between 1 and 5 per cent; * between 5 and 10 per cent. Marginal effects are the partial change in the probability with respect to the change of each independent variables, evaluated at the sample means, multiplied by 10,000 .

\begin{tabular}{|c|c|c|c|c|c|c|c|}
\hline & \multicolumn{2}{|c|}{ Binomial specification } & \multicolumn{5}{|c|}{ Multinomial specification } \\
\hline & \multirow[t]{2}{*}{ Coefficients } & \multirow[t]{2}{*}{ Marginal } & \multicolumn{2}{|c|}{ Coefficients } & \multicolumn{2}{|c|}{ Marginal effects } & \multirow[b]{2}{*}{ Difference } \\
\hline & & & Domestic & Cross-border & Domestic & Cross-border & \\
\hline & (1) & (2) & (3) & (4) & (5) & (6) & (7) \\
\hline \multicolumn{8}{|c|}{ Panel A - Country characteristics } \\
\hline GDP $(\log )$ & $\begin{array}{l}0.2535 * \\
(0.1483)\end{array}$ & 388.527 & $\begin{array}{l}0.4843 * * \\
(0.1947)\end{array}$ & $\begin{array}{l}-0.0623 \\
(0.2439)\end{array}$ & 348.621 & 5.089 & $*$ \\
\hline Bank Concentration & $\begin{array}{l}0.4319 \\
(0.8135)\end{array}$ & 661.854 & $\begin{array}{l}0.1494 \\
(0.9683)\end{array}$ & $\begin{array}{l}1.1659 \\
(1.2508)\end{array}$ & 72.090 & 371.046 & \\
\hline St.mkt cap. / Pr. Cr. & $\begin{array}{l}-0.6345^{* * *} \\
(0.2222)\end{array}$ & -972.355 & $\begin{array}{l}-0.873 * * * \\
(0.2894)\end{array}$ & $\begin{array}{l}-0.8708 * * \\
(0.3989)\end{array}$ & -605.553 & -253.539 & \\
\hline Private Credit /GDP & $\begin{array}{l}-0.3938 \\
(0.3414)\end{array}$ & -603.467 & $\begin{array}{l}-0.7171 \\
(0.5127)\end{array}$ & $\begin{array}{l}-0.8207 \\
(0.5137)\end{array}$ & -495.505 & -242.190 & \\
\hline \multicolumn{8}{|c|}{ Panel B - Individual bank characteristics (net of country and year averages) } \\
\hline Total Assets (log) & $\begin{array}{l}0.3373 * * \\
(0.1389)\end{array}$ & 516.887 & $\begin{array}{l}0.3054 * * \\
(0.1488)\end{array}$ & $\begin{array}{l}1.0123 * * * \\
(0.1579)\end{array}$ & 189.723 & 316.719 & $* * *$ \\
\hline Return on Assets & $\begin{array}{l}0.3676^{* * * *} \\
(0.0584)\end{array}$ & 56.340 & $\begin{array}{l}0.4185 * * * \\
(0.1086)\end{array}$ & $\begin{array}{l}0.4927 * * * \\
(0.1615)\end{array}$ & 287.643 & 145.788 & \\
\hline Liq. Asset / Deposits & $\begin{array}{l}-0.0181 * * * \\
(0.0054)\end{array}$ & -27.575 & $\begin{array}{l}-0.0294 * * * \\
(0.0075)\end{array}$ & $\begin{array}{l}-0.0018 \\
(0.0062)\end{array}$ & -21.250 & 0.302 & $* * *$ \\
\hline Oth. Inc /Tot. & $\begin{array}{l}-0.4676 * * * \\
(0.1818)\end{array}$ & -716.668 & $\begin{array}{l}-0.5958 * * \\
(0.6046)\end{array}$ & $\begin{array}{l}-0.4966 * * * \\
(0.1713)\end{array}$ & -415.821 & -141.583 & \\
\hline Equity / Assets & $\begin{array}{l}-0.0258 \\
(0.0287)\end{array}$ & -39.574 & $\begin{array}{l}-0.0411 \\
(0.0406)\end{array}$ & $\begin{array}{l}0.0568 \\
(0.0458)\end{array}$ & -31.531 & 19.593 & $* *$ \\
\hline Cost / Income & $\begin{array}{l}0.0008 * * \\
(0.0035)\end{array}$ & 13.079 & $\begin{array}{l}0.0111 * * \\
(0.0054)\end{array}$ & $\begin{array}{l}0.0135 * * \\
(0.0064)\end{array}$ & 7.623 & 4.017 & \\
\hline \multicolumn{8}{|c|}{ Panel C-Average bank characteristics (by year and country) } \\
\hline Total Asset (log) & $\begin{array}{l}0.0152 \\
(0.2372)\end{array}$ & 23.342 & $\begin{array}{l}-0.4045^{* *} \\
(0.1600)\end{array}$ & $\begin{array}{l}-0.3146^{*} \\
(0.1821)\end{array}$ & -283.040 & -88.837 & \\
\hline Return on Assets & $\begin{array}{l}1.1862 * * * \\
(0.3227)\end{array}$ & 1817.813 & $\begin{array}{l}0.7180 * \\
(0.3683)\end{array}$ & $\begin{array}{l}1.4824 * * * \\
(0.5697)\end{array}$ & 477.376 & 455.410 & \\
\hline Liq. Asset / Deposits & $\begin{array}{l}-0.0247 * * \\
(0.0120)\end{array}$ & -37.866 & $\begin{array}{l}-0.0344 * * \\
(0.0172)\end{array}$ & $\begin{array}{l}-0.0385^{* *} \\
(0.0166)\end{array}$ & -23.719 & -11.340 & \\
\hline Oth. Inc /Tot. & $\begin{array}{l}-0.3422 \\
(0.2134)\end{array}$ & -524.518 & $\begin{array}{l}-0.3528 \\
(0.2839)\end{array}$ & $\begin{array}{l}-0.0238 \\
(0.3103)\end{array}$ & -254.638 & 3.237 & \\
\hline Equity / Assets & $\begin{array}{l}-0.1167 \\
(0.0758)\end{array}$ & -178.906 & $\begin{array}{l}-0.0321 \\
(0.0957)\end{array}$ & $\begin{array}{l}-0.2523 * \\
(0.1370)\end{array}$ & -15.431 & -80.320 & $*$ \\
\hline Cost / Income & $\begin{array}{l}0.0156 \\
(0.0123)\end{array}$ & 24.021 & $\begin{array}{l}0.0203 \\
(0.0187)\end{array}$ & $\begin{array}{l}0.0175 \\
(0.0164)\end{array}$ & 14.187 & 5.013 & \\
\hline Observations & 4,803 & & 5,301 & 5,301 & & & \\
\hline
\end{tabular}




\section{Characteristics of bank M\&A bidders - G10 countries}

In the binomial specification, the dependent variable takes the value of one if the bank is a bidder in any M\&A and zero otherwise. In the multinomial specification, the dependent variable takes the value of two if the bank is a bidder in a crossborder M\&A, one if it is a bidder in a domestic M\&A and zero otherwise. Both models are estimated using a (binomial or multinomial) probit specification. All independent variables are lagged one period. For variable definitions see the notes to Tables 1-3. Robust standard errors adjusted for clustering at the country level are reported in parenthesis. Panel 7 reports the significance of the test of the difference between the coefficients of domestic deals (Panel 3) and of cross-border deals (Panel 4). The symbol *** indicates a significance level of 1 per cent or less; ** between 1 and 5 per cent; * between 5 and 10 per cent. Marginal effects are the partial change in the probability with respect to the change of each independent variables, evaluated at the sample means, multiplied by 10,000 .

\begin{tabular}{|c|c|c|c|c|c|c|c|}
\hline & \multicolumn{2}{|c|}{ Binomial specification } & \multicolumn{5}{|c|}{ Multinomial specification } \\
\hline & \multirow[t]{2}{*}{ Coefficients } & \multirow{2}{*}{ Marginal } & \multicolumn{2}{|c|}{ Coefficients } & \multicolumn{2}{|c|}{ Marginal effects } & \multirow[b]{2}{*}{ Difference } \\
\hline & & & Domestic & Cross-border & Domestic & Cross-border & \\
\hline & (1) & (2) & (3) & (4) & (5) & (6) & (7) \\
\hline \multicolumn{8}{|c|}{ Panel A - Country characteristics } \\
\hline GDP $(\log )$ & $\begin{array}{l}1.2883 * * * \\
(0.3779)\end{array}$ & 2018.045 & $\begin{array}{l}0.6587 * * \\
(0.2959)\end{array}$ & $\begin{array}{l}0.0678 \\
(0.2679)\end{array}$ & 533.887 & -5.704 & \\
\hline Bank Concentration & $\begin{array}{l}1.5257 \\
(1.0351)\end{array}$ & 2389.885 & $\begin{array}{l}0.9110 \\
(0.9284)\end{array}$ & $\begin{array}{l}-2.4113 \\
(1.9248)\end{array}$ & 806.095 & -454.266 & $*$ \\
\hline St.mkt cap. / Pr. Cr. & $\begin{array}{l}-1.2950 * * * \\
(0.1368)\end{array}$ & -2028.417 & $\begin{array}{l}-1.1021^{* * *} \\
(0.3110)\end{array}$ & $\begin{array}{l}-2.7360 * * * \\
(0.6445)\end{array}$ & -822.430 & -457.717 & $* *$ \\
\hline Private Credit /GDP & $\begin{array}{l}-0.5685^{*} \\
(0.3436)\end{array}$ & -890.608 & $\begin{array}{l}-0.1442 \\
(0.4576)\end{array}$ & $\begin{array}{l}-0.6527 \\
(0.6101)\end{array}$ & -99.692 & -112.399 & \\
\hline \multicolumn{8}{|c|}{ Panel B - Individual bank characteristics (net of country and year averages) } \\
\hline Total Assets $(\log )$ & $\begin{array}{l}0.3203 * \\
(0.1703)\end{array}$ & 501.694 & $\begin{array}{l}0.2976 * * \\
(0.1331)\end{array}$ & $\begin{array}{l}1.1800 * * * \\
(0.1678)\end{array}$ & 210.195 & 202.216 & $* * *$ \\
\hline Return on Assets & $\begin{array}{l}0.3117 * * * \\
(0.0499)\end{array}$ & 488.375 & $\begin{array}{l}0.4193 * \\
(0.2267)\end{array}$ & $\begin{array}{l}0.4121 \\
(0.2896)\end{array}$ & 329.936 & 62.106 & \\
\hline Liq. Asset / Deposits & $\begin{array}{l}-0.0281 * * * \\
(0.0108)\end{array}$ & -44.103 & $\begin{array}{l}-0.0364 * * \\
(0.0153)\end{array}$ & $\begin{array}{l}-0.0203 \\
(0.0158)\end{array}$ & -29.072 & -2.649 & \\
\hline Oth. Inc /Tot. Income & $\begin{array}{l}-0.4203 * * \\
(0.2148)\end{array}$ & -658.355 & $\begin{array}{l}-0.5896 * * \\
(0.2983)\end{array}$ & $\begin{array}{l}-0.7040 * * * \\
(0.2716)\end{array}$ & -460.501 & -109.511 & \\
\hline Equity / Assets & $\begin{array}{l}-0.0411 \\
(0.0340)\end{array}$ & -64.445 & $\begin{array}{l}-0.0580 \\
(0.0530)\end{array}$ & $\begin{array}{l}0.0891 \\
(0.0916)\end{array}$ & -49.623 & 17.459 & * \\
\hline Cost / Income & $\begin{array}{l}0.0117 * * \\
(0.0052)\end{array}$ & 18.418 & $\begin{array}{l}0.0125 \\
(0.0086)\end{array}$ & $\begin{array}{l}0.0208 * * * \\
(0.0071)\end{array}$ & 9.656 & 3.384 & \\
\hline \multicolumn{8}{|c|}{ Panel $C-$ Average bank characteristics (by year and country) } \\
\hline Total Asset (log) & $\begin{array}{l}0.5392 * * * \\
(0.1965)\end{array}$ & 844.575 & $\begin{array}{l}-0.5981 * * * \\
(0.1735)\end{array}$ & $\begin{array}{l}-0.3105 * \\
(0.1704)\end{array}$ & -478.095 & -39.164 & \\
\hline Return on Assets & $\begin{array}{l}-0.0845^{* * * *} \\
(0.0189)\end{array}$ & -133.393 & $\begin{array}{l}-0.0608 * * * \\
(0.0193)\end{array}$ & $\begin{array}{l}-0.0591 * * \\
(0.0287)\end{array}$ & -47.890 & -8.893 & \\
\hline Liq. Asset / Deposits & $\begin{array}{l}2.5068 * * * \\
(0.4526)\end{array}$ & 3926.489 & $\begin{array}{l}1.6534 * * * \\
(0.5496)\end{array}$ & $\begin{array}{l}7.0612 * * * \\
(1.5158)\end{array}$ & 1153.943 & 1213.481 & $* * *$ \\
\hline Oth. Inc /Tot. Income & $\begin{array}{l}-0.7106 * \\
(0.3641)\end{array}$ & -1113.055 & $\begin{array}{l}-0.1947 \\
(0.3924)\end{array}$ & $\begin{array}{l}0.2481 \\
(0.5373)\end{array}$ & -165.079 & 49.472 & \\
\hline Equity / Assets & $\begin{array}{l}-0.2732 * * * \\
(0.0736)\end{array}$ & -428.035 & $\begin{array}{l}-0.0759 \\
(0.2294)\end{array}$ & $\begin{array}{l}-1.0541^{* * * *} \\
(0.2510)\end{array}$ & -33.258 & -185.770 & $* * *$ \\
\hline Cost / Income & $\begin{array}{l}0.0459 \\
(0.0320)\end{array}$ & 71.929 & $\begin{array}{l}0.0266 \\
(0.0220)\end{array}$ & $\begin{array}{l}0.0505 * \\
(0.0295)\end{array}$ & 20.316 & 8.286 & \\
\hline Observations & 3,381 & & 4,025 & 4,025 & & & \\
\hline
\end{tabular}

